DuBois, K. P. \& Potter, V. R. (1943). J. biol. Chem. 147, 41.

Evelyn, K. A. \& Malloy, H. T. (1938). J. biol. Chem. 126, 655.

Gibson, Q. H. (1943). Biochem. J. 37, 615.

Gibson, Q. H. \& Harrison, D. C. (1945). Biochem. J. 39, 490.

Green, D. E. \& Brosteaux, J. (1936). Biochem. J. 30, 1489.

Green, D. E. \& Williamson, S. (1940). J. biol. Chem. 135, 345.

Jost, H. (1927). Hoppe-Seyl. Z. 165, 171.

Lian, C., Frumusan, P. \& Sassier, M. (1939). Bull. Soc. méd. Hôp. Paris, 55, 1194.

Lohmann, K. \& Meyerhof, O. (1934). Biochem. Z. 273, 60.

Long, C. (1942). Biochem. J. 36, 807.

Meyerhof, O. \& Schulz, W. (1938). Biochem. Z. 297, 60.

Morgan, W. J. T. \& Robison, R. (1930). Biochem. J. 24, 119.

Needham, D. M. \& Pillai, R. K. (1937). Biochem. J. 31, 1837.
Neuberg, C. \& Vercellone, A. (1935). Biochem. Z. 280, 161.

Ohlmeyer, P. (1938). Biochem. Z. 297, 66.

Paul, W. D. \& Kemp, C. R. (1944). Proc. Soc. exp. Biol., N.Y., 56, 55.

Peters, R. A. (1938). Biochem. J. 32, 2031.

Peters, J. P. \& Van Slyke, D. D. (1931). Quantitative Clinical Chemistry, Interpretations, p. 631. London: Baillière, Tindall and Cox.

Rapoport, S. (1936). Biochem. Z. 289, 406.

Robison, R. (1922). Biochem. J. 16, 809.

Sievers, R. F. \& Ryon, J. B. (1946). Arch. intern. Med. 76, 299.

Stadie, W. C. (1921). J. exp. Med. 33, 627.

Straub, F. B. (1939). Biochem. J. 33, 787.

Warburg, O. \& Christian, W. (1931). Biochem. Z. 242, 174.

Warburg, O., Christian, W. \& Griese, A. (1935). Biochem. Z. $282,157$.

Warburg, O., Kubowitz, F. \& Christian, W. (1930). Biochem. Z. 227, 245.

\title{
Studies on Glyoxalase
}

\author{
1. A NEW FACTOR \\ By the LATE F. GOWLAND HOPKINS AND E. J. MORGAN \\ Biochemical Laboratory, University of Cambridge
}

(Received 16 April 1947)

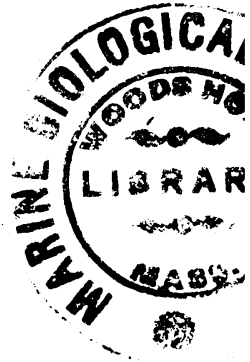

The experiments to be described took origin from a personal observation by one of us (E.J.M.). He found that the enzyme glyoxalase was well adsorbed

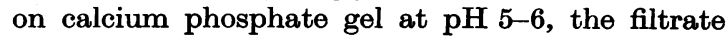
showing no activity at all in the presence of methylglyoxal and glutathione. When, however, a proportionate amount of the filtrate was added to the eluate from the calcium phosphate the activity of this was largely increased.

\section{EXPERIMENTAL}

\section{General methods}

The method was that used in our previous paper (Hopkins \& Morgan, 1945), namely, the determination of the rate of $\mathrm{CO}_{2}$ evolution from $\mathrm{NaHCO}_{3}$ solution, due to lactic acid production from methylglyoxal. We employed Barcroft differential manometers provided with standardized flasks. Each flask contained a measured quantity of the enzyme solution or other preparations, $0.6 \mathrm{ml}$. of $0.2 \mathrm{M}-\mathrm{NaHCO}_{3}$, with $2 \mathrm{mg}$. of glutathione (GSH) in $0.3 \mathrm{ml}$. water in a Keilin cup. To one flask $2.1 \mathrm{mg}$. of methylglyoxal were added, and the total contents of each flask made up to $3 \mathrm{ml}$. with distilled water (any variation of these quantities is given in the text). The apparatus was filled with a gas mixture of 95 vol. $\mathrm{N}_{2}+5$ vol. $\mathrm{CO}_{2}$, the GSH tipped in and the manometer shaken in a bath at $25^{\circ}$. The stopcocks were left open for $4 \mathrm{~min}$. and then closed.
The majority of our experiments were carried out with ox heart, as this was the most convenient tissue to obtain fresh in sufficient quantities. Acetone preparations of the hearts were prepared. In making these, owing to the scarcity of acetone, smaller quantities were used than usual. The hearts freed from fat were minced, and extracted at $0^{\circ}$ with three times their weight of acetone for $30 \mathrm{~min}$., filtered, and extracted a second time for $15 \mathrm{~min}$., using half the previous volume of acetone. The extracted heart was filtered off and dried in large vacuum desiccators. It was then ground to a fine powder in a mill. This acetone heart powder if kept dry keeps its activity for several months.

\section{Separation of the new factor from the enzyme}

The following separation was repeated several times; the results are shown in Table 1.

lst stage. $80 \mathrm{~g}$. of acetone heart powder were extracted by stirring with $400 \mathrm{ml}$. of distilled water for $1 \mathrm{hr}$. and then centrifuged. The supernatant, which was highly pigmented, measured $234 \mathrm{ml}$. Of this, $0 \cdot 3 \mathrm{ml}$. (dry wt. $9.90 \mathrm{mg}$.) gave $303 \cdot 2 \mu \mathrm{l} . \mathrm{CO}_{2}$ in $20 \mathrm{~min}$.

2nd stage. Fractional precipitation with ammonium sulphate. To $220 \mathrm{ml}$. of the supernatant, solid ammonium sulphate (68.64 g.) was slowly added to give $50 \%$ saturation. After standing $2 \mathrm{hr}$. the precipitate was centrifuged off and discarded. 
The filtered, clear supernatant measured $234 \mathrm{ml}$. The ammonium sulphate concentration was then raised to $70 \%$ saturation by adding the calculated amount of the solid (31.6 g.). After standing overnight in the refrigerator, the precipitate, which contained both the factor and the enzyme, was filtered off on two ordinary funnels, and given one good wash by filling up the papers with $70 \%$ saturated ammonium sulphate. The precipitate was scraped off the paper, dissolved in about $50 \mathrm{ml}$. of distilled water and dialyzed in cellophan tubing against distilled water, with frequent changes, for 18-24 hr. An inactive precipitate.was centrifuged off and the supernatant diluted to $110 \mathrm{ml}$. (i.e. half the volume originally taken). The $\mathrm{pH}$ of this solution was approximately 5.4 and needed no adjustment for the next stage. $0.3 \mathrm{ml}$. (dry wt. $5.25 \mathrm{mg}$.) gave $302.5 \mu \mathrm{l} . \mathrm{CO}_{2}$ in $20 \mathrm{~min}$. '

3 rd stage. Adsorption of the enzyme. $100 \mathrm{ml}$. of the above solution were used for this stage. The enzyme was completely adsorbed on calcium phosphate gel suspension (30 mg. dry wt. $/ \mathrm{ml}$.) by adding four successive lots of $10 \mathrm{ml}$., allowing each to stand $15 \mathrm{~min}$. with an occasional stir, and then each time centrifuging off the gel. The supernatant contained the factor (see Table 1). $0.42 \mathrm{ml}$. (dry wt. $3.24 \mathrm{mg}$.), equivalent to $0.3 \mathrm{ml}$. of the $100 \mathrm{ml}$. taken for stage 3 , gave 21.0 $\mu \mathrm{l}$. $\mathrm{CO}_{2}$ in $20 \mathrm{~min}$.

Elution of the enzyme. The four lots of calcium phosphate gel containing the enzyme were mixed, and washed well by stirring with $200 \mathrm{ml}$. of distilled water to which was added $10 \mathrm{ml}$. of Sørensen's phosphate buffer pH 5.4. This washing was repeated three times. The enzyme was then eluted from the calcium phosphate by two successive extractions with phosphate buffer $\mathrm{pH} 7.8$ containing $10 \%$ (w/v) ammonium sulphate, 50 and $20 \mathrm{ml}$. respectively being added., The two eluates were mixed, dialyzed for $24 \mathrm{hr}$., made up to $100 \mathrm{ml}$. and a very small inactive precipitate filtered off. Of the enzyme solution $0.3 \mathrm{ml}$. (dry wt. 1.5 mg.) gave $123.3 \mu \mathrm{l} . \mathrm{CO}_{2}$ in $20 \mathrm{~min}$.; $0.3 \mathrm{ml}$. enzyme $+0.42 \mathrm{ml}$. of factor gave $279.0 \mu \mathrm{l} . \mathrm{CO}_{2}$ in $20 \mathrm{~min}$. Other results are shown in Table 1. Preparations 1 and 2 were made from separate supplies of hearts.

It will be seen from the results (Table 1) that the presence of the factor has in each case more than doubled the velocity of action of the enzyme alone, the average increase being $141.7 \%$. In each case the enzyme and factor are equivalent to the same weight of heart powder.

\section{Nature of the action of the factor}

It is apparent from Fig. 1 that the effect of the factor is accelerative, maximal $\mathrm{CO}_{2}$ liberation with enzyme + factor being attained in $20 \mathrm{~min}$.; with enzyme alone in $140 \mathrm{~min}$. The stopcocks were open

\section{Table 1. Evidence for the new factor}

Acid production from methylglyoxal ( $\mu \mathrm{l}$. $\mathrm{CO}_{2}$ evolved from $\mathrm{NaHCO}_{8}$ in $20 \mathrm{~min}$.)

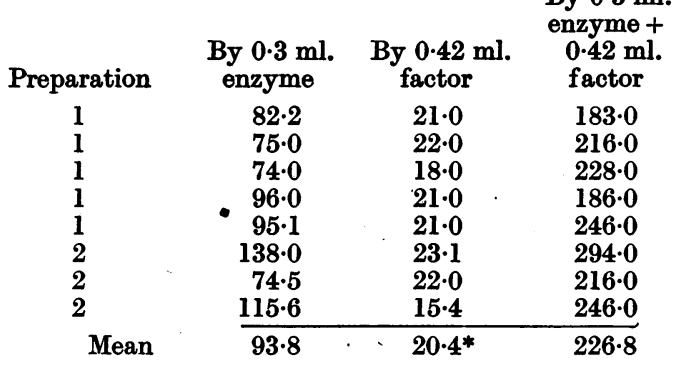

* This small reading is not of enzymic origin, but due to some chemical action between GSH and methylglyoxal (Jowett \& Quastel, 1933; Hopkins \& Morgan, 1945).

in this experiment for $5 \mathrm{~min}$., therefore the $\mu \mathrm{l}$. of $\mathrm{CO}_{2}$ evolved during this time, which we may take from the curves to be 60.0 and 25.27 respectively, must be added to the amount evolved (Fig. 1) affording totals for the enzyme + factor of $\mathbf{2 8 2 . 7}$ and for the enzyme alone of $282 \cdot 0 \mu \mathrm{l}$.

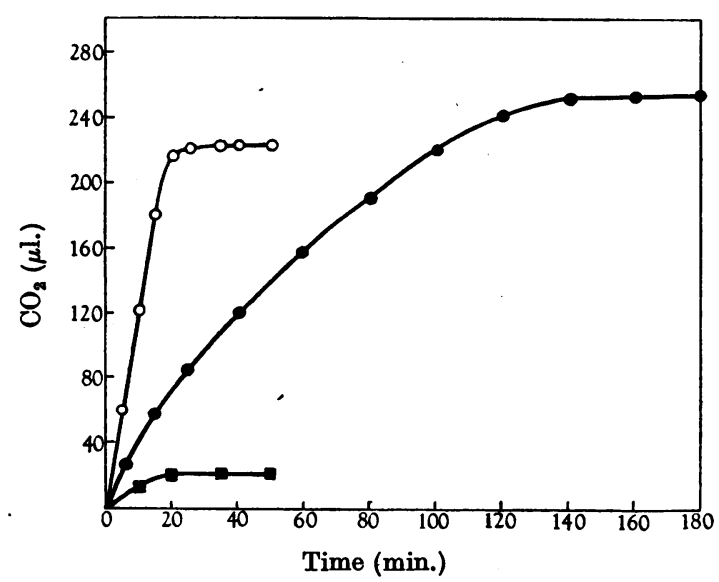

Fig. 1. Effect of factor on the action of glyoxalase. Curve $-0,0.3 \mathrm{ml}$. enzyme; $\square-\square, 0.42 \mathrm{ml}$. factor; $\mathrm{O}-\mathrm{O}, 0.3 \mathrm{ml}$. enzyme $+0.42 \mathrm{ml}$. factor. $1.0 \mathrm{mg}$. methylglyoxal and $2.0 \mathrm{mg}$. GSH in each. The dry weight of $0.3 \mathrm{ml}$. enzyme was $1.65 \mathrm{mg}$. and of $0.42 \mathrm{ml}$. factor $0.82 \mathrm{mg}$.

\section{Further purification and properties of the factor}

The factor was further purified by the following three additional stages.

$4 t h$ stage. To $112 \mathrm{ml}$. of the supernatant (stage 3) $45.9 \mathrm{~g}$. of ammonium sulphate were slowly added giving a final concentration of $63 \%$ saturation. After standing $2 \mathrm{hr}$. the precipitate was filtered off 
and washed with $63 \%$ saturated ammonium sulphate. The precipitate was scraped off the filter paper, dissolved in distilled water, dialyzed $18 \mathrm{hr}$. and made up to $80 \mathrm{ml}$. (this is the same dilution as the finish of stage 2). Of this solution $0.3 \mathrm{ml}$. (dry wt. $0.82 \mathrm{mg}$.) $+0.3 \mathrm{ml}$. enzyme gave $267.0 \mu \mathrm{l} . \mathrm{CO}_{2}$ in $20 \mathrm{~min}$.

5th stage. The solution was adjusted to $\mathrm{pH} \mathbf{7 \cdot 3}$ with sodium bicarbonate and heated in a water bath to $55^{\circ}$ for $1 \mathrm{~min}$. The solution was quickly cooled and the coagulum centrifuged off. Of the supernatant $0.3 \mathrm{ml}$. (dry wt. $0.38 \mathrm{mg}$.) $+0.3 \mathrm{ml}$. enzyme gave $237.0 \mu \mathrm{l} . \mathrm{CO}_{2}$ in $20 \mathrm{~min}$. It will be seen that there was some loss in activity of this particular preparation by heating. In all subsequent preparations there was no loss by heating to $\mathbf{5 5}^{\circ}$.

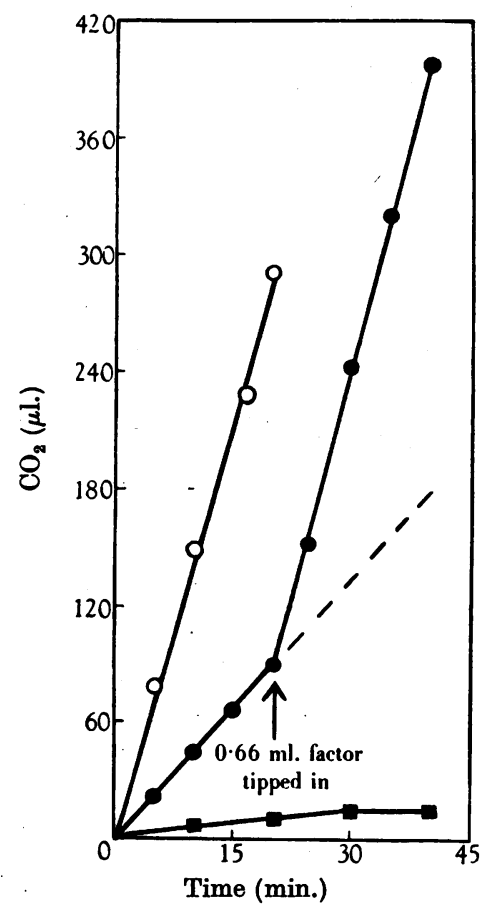

Fig. 2. Promptness of action of the factor. Curve $\mathrm{O}-\mathrm{O}$, $0.3 \mathrm{ml}$. enzyme $+0.66 \mathrm{ml}$. factor; $-0,0.3 \mathrm{ml}$. enzyme, with $0.66 \mathrm{ml}$. factor tipped in at arrow; $\square-\square, 0.66 \mathrm{ml}$. factor, $2 \cdot 0 \mathrm{mg}$. GSH and $2 \cdot 1 \mathrm{mg}$. methylglyoxal in each. The dry weight of $0.3 \mathrm{ml}$. enzyme was $1.0 \mathrm{mg}$., and of $0.66 \mathrm{ml}$. factor $0.308 \mathrm{mg}$.

6 th stage. $50 \mathrm{ml}$. were adjusted to $\mathrm{pH} 5.4$ with dilute acetic acid and $5 \mathrm{ml}$. of calcium phosphate gel added (in later preparations $20 \mathrm{ml}$. were used). After standing $15 \mathrm{~min}$. the calcium phosphate was centrifuged off and discarded. $0.33 \mathrm{ml}$. (dry wt. $0.154 \mathrm{mg}$.) $+0.3 \mathrm{ml}$. enzyme gave $201.0 \mu \mathrm{l} . \mathrm{CO}_{2}$ in $20 \mathrm{~min}$. For the dry weight of the 5 th and 6 th stage, measured portions were dialyzed. At this stage the solution was crystal clear. The factor can be concentrated by precipitating with ammonium sulphate (final concentration $63 \%$ saturated) taking the precipitate up in the minimal quantity of distilled water and dialyzing until free from ammonium sulphate. Working on a much larger scale the solutions were kept more concentrated after the 2nd stage. One large scale attempt to crystallize the factor from ammonium sulphate failed, the activity decreasing, probably due to the acidity of the ammonium sulphate. In the following experiments we used the purified factor.

Action of factor immediate. The factor prepared as above exerts its full effect immediately it is added to the system, i.e. without lapse of time for any interaction with the reactants; this is shown in Fig. 2.

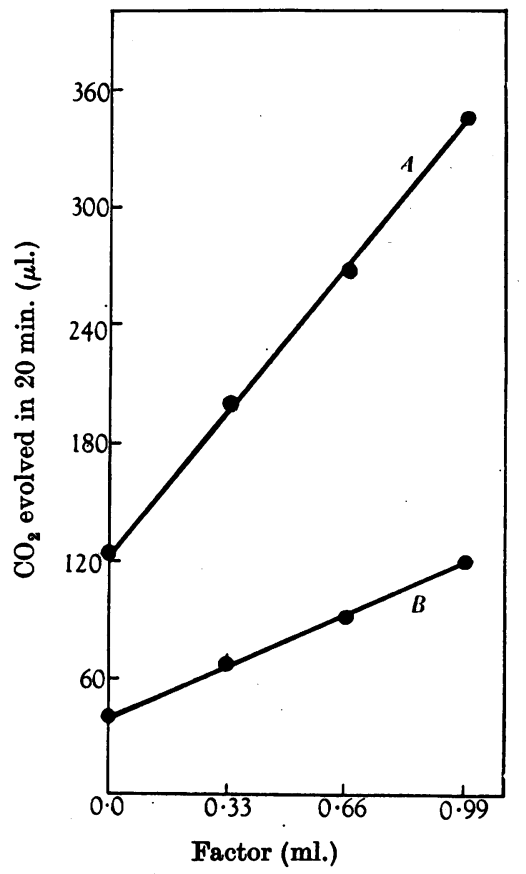

Fig. 3. Effects of varying quantities of the factor on glyoxalase action. $0.3 \mathrm{ml}$. of enzyme in each Barcroft flask, with varying amounts of factor. Dry weights the same as Fig. 2. Curve $A$ with $2.0 \mathrm{mg}$. GSH, and curve $B$ with $0.25 \mathrm{mg}$. GSH; $2 \cdot 1 \mathrm{mg}$. methylglyoxal in each.

Variation of velocity of reaction with factor concentration. Fig. 3 shows the effect on the velocity of reaction of increasing the concentration of the factor with a constant volume of enzyme.

Dependence of action by the factor upon presence of GSH. Three Barcrofts were set up as follows: $A$, one flask with $0.3 \mathrm{ml}$. enzyme ( $1.0 \mathrm{mg}$. $)+0.6 \mathrm{ml}$. factor (0.2 mg.) + GSH but no methylglyoxal; the other flask. with $2.4 \mathrm{ml}$. water $+0.6 \mathrm{ml}$. bicarbonate; $B$, with enzyme + factor + methylglyoxal but no GSH; 
$C$, with enzyme + factor + methylglyoxal + GSH. There was no $\mathrm{CO}_{2}$ evolution in $A$ and $B$, whilst in $C$, $207 \cdot 0 \mu \mathrm{l} . \mathrm{CO}_{2}$ were evolved in $20 \mathrm{~min}$.

\section{Experiments with phenylglyoxal as the substrate}

Using preparations of glyoxalase as ordinarily made, the velocity of the reaction was very much slower with phenylglyoxal than with methylglyoxal. Equimolar quantities of the substrates were used. The results are shown in Table 2. The enzyme preparations were made by grinding $10 \mathrm{~g}$. of tissue with $30 \mathrm{ml}$. of water in a mortar for 30 min., using a little sand, and then centrifuging. The supernatant was dialyzed for $24 \mathrm{hr}$., made up to $50 \mathrm{ml}$. and filtered. $0.3 \mathrm{ml}$. of the preparations were used in the Barcroft.

Relation of the factor to phenylglyoxal. In Table 3 it will be seen that when the enzyme is separated from the factor, the former acts with about equal velocity on methyl- and phenylglyoxal. When, however, the
Table 2. Methyl and phenylglyoxals as substrates

$\mathrm{CO}_{2}$ evolved from $\mathrm{NaHCO}_{3}$ $(\mu \mathrm{l}$.

$\begin{array}{lcrc}\text { Tissue } & \begin{array}{c}\text { Time } \\ \text { (min.) }\end{array} & \begin{array}{c}\text { phenyl- } \\ \text { glyoxal }\end{array} & \begin{array}{c}\text { glyoxal } \\ \text { methyl- }\end{array} \\ \text { Ox heart } & 20 & 77 \cdot 1 & 135 \cdot 0 \\ \text { Ox liver } & 10 & 90 \cdot 0 & 287 \cdot 8 \\ \text { Rat liver } & 10 & 72 \cdot 0 & 225 \cdot 0 \\ \text { Rat erythrocytes } & 10 & 108 \cdot 0 & 237 \cdot 0 \\ \text { Sheep liver } & 10 & 90.0 & 315 \cdot 0 \\ \text { Pig liver } & 20 & 180.0 & 309 \cdot 0 \\ \text { Acetone ox heart } & 20 & 99 \cdot 0 & 300 \cdot 0 \\ \text { Acetone yeast } & 20 & 138 \cdot 0 & 223 \cdot 6\end{array}$

factor is added to the enzyme, it greatly increases the velocity of reaction with methylglyoxal whereas in the case of phenylglyoxal it produces no effect.

It will be seen from the following table (Table 4) that phenylglyoxal combines with the factor. On adding phenyl and methylglyoxal in equimolar proportions to the enzyme + factor (Exp. G) there was

Table 3. Differential effect of the factor on reaction with methylglyoxal

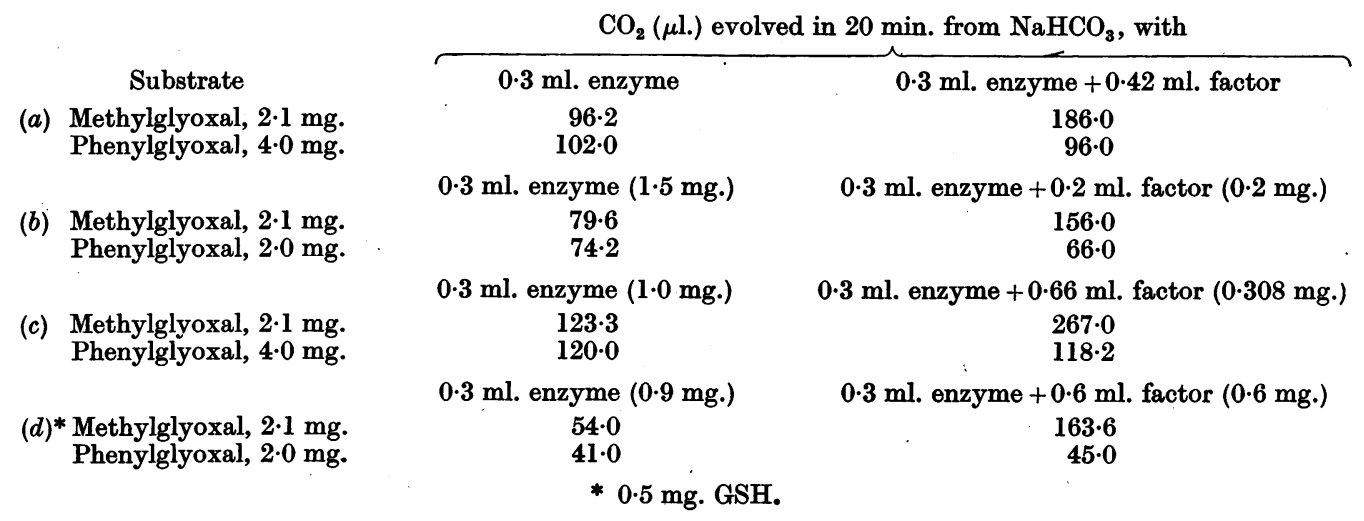

Table 4. Combination of the factor with phenylglyoxal

(The reactants were measured into the Barcroft flasks in the following order: water, bicarbonate, 0.3 ml. enzyme, $0.6 \mathrm{ml}$. factor, methylglyoxal, phenylglyoxal, and $0.5 \mathrm{mg}$. GSH tipped in. Dry weights in experiments A-I: 0.3 ml. enzyme, $0.99 \mathrm{mg}$.; $0.6 \mathrm{ml}$. factor, $0.6 \mathrm{mg}$. J-L, and $\mathrm{M}$ and $\mathrm{N}$, contained different preparations of the enzyme and factor. The final concentrations of the substrates are given in brackets.)

Exp.
$\mathbf{A}$
$\mathbf{B}$
$\mathbf{C}$
$\mathbf{D}$
$\mathbf{E}$
$\mathbf{F}$
$\mathbf{G}$
$\mathbf{H}$
$\mathbf{I}$
$\mathbf{J}$
$\mathbf{K}$
$\mathbf{L}$
$\mathbf{M}$
$\mathbf{N}$

Reaction mixture

$\mathrm{CO}_{2}$ evolved
in 20 min.
$(\mu \mathrm{l}$.
$41 \cdot 1$
$105 \cdot 0$
$41 \cdot 1$
$42 \cdot 0$
$42 \cdot 0$
$36 \cdot 0$
$42 \cdot 0$
$66 \cdot 0$
$74 \cdot 5$
$123 \cdot 0$
$56 \cdot 5$
$111 \cdot 0$
$156 \cdot 0$
$154 \cdot 0$

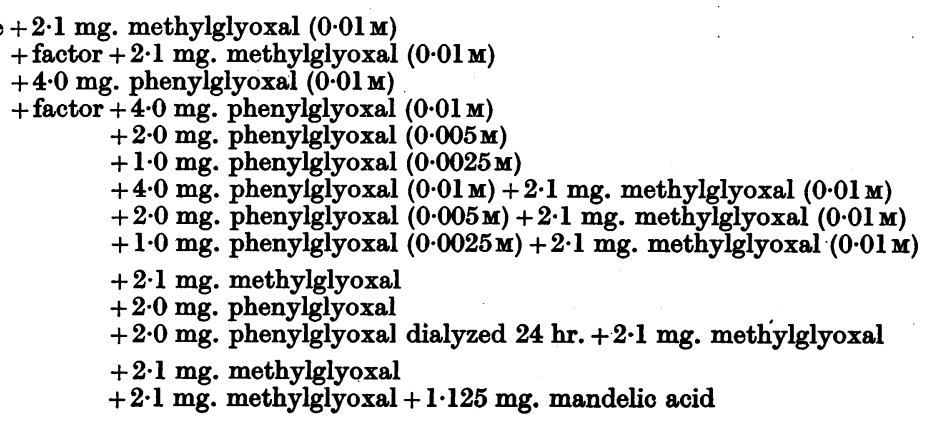

$154 \cdot 0$ 
no increase in velocity; lowering the amount of phenylglyoxal so that the methylglyoxal was in the proportion of 2 to 1 (Exp. $H$ ) gave an increase of $24 \mu \mathrm{l} . \mathrm{CO}_{2}$ evolved, and a 4 to 1 ratio (Exp. I) gave $32.5 \mu$ l. This shows that phenylglyoxal has the greater affinity for the factor but the velocity of its enzymic decomposition is not increased as is the case with methylglyoxal. That the phenylglyoxal can be dialyzed away from the factor is shown by Exps. J, $K$ and $L$. Mandelic acid does not inhibit in concentrations that would be formed during the experiments (Exps. $M$ and $N$ ).

The factor is protein in nature, or closely associated with a protein. The solutions give good biuret and ninhydrin reactions, and positive colour tests for tyrosine, tryptophan, arginine, histidine and cystine.

The purest preparation of the factor we have so far prepared, when used in a quantity of $0.1 \mathrm{mg}$. with $1.0 \mathrm{mg}$. of enzyme, increased the velocity of reaction by $66 \cdot 6 \%$. The activity was completely destroyed by heating at $70^{\circ}$ for $3 \mathrm{~min}$.

\section{DISCUSSION}

It will be seen from the results of the experiments described above that when methyl- and phenylglyoxal are added to a preparation of glyoxalase as ordinarily made from a tissue, the velocity of the reaction with the former is often more than three times that with the latter substrate (Table 2).

Lohmann (1932), in his experiments showing that glutathione was the coenzyme for glyoxalase, obtained this effect with either (he did not state which) rat or rabbit liver.

There seems to be no doubt that this increased velocity, when methylgilyoxal is the substrate, is due to the new factor which we have separated and purified. We have shown that when the enzyme and factor are separated, the velocity of the reaction with the enzyme alone is the same for both substrates. But when the factor is added to the enzyme it is only the methylglyoxal which shows increased velocity, the phenylglyoxal giving the same evolution of $\mathrm{CO}_{2}$ as for the enzyme alone (Table 3). This is shown to be due to the fact that, although phenylglyoxal combines with the factor, such combination does not increase the velocity of reaction (Table 4). We have emphasized earlier (Fig. 1) that the essential effect of the presence of the factor is an accelerative one.

In respect of the separation of the enzyme from the factor, it was successful enough in that solutions of the latter show no trace of enzyme activity. It is possible that the partially purified preparations of the enzyme as described, might leaveit in association with small quantities of the factor, and that these are responsible for, and essential to, the action of the enzyme on methylglyoxal. It seems to us that strong evidence against this is yielded by the identical velocity of reaction displayed when methyland phenylglyoxal react with our preparations of the enzyme. Since the factor has no effect in the case of phenylglyoxal, it would if present as an impurity secure a greater velocity for the methylglyoxal. Furthermore, as the factor is completely inhibited by phenylglyoxal (Table 4), any traces left in the enzyme solution would also be inhibited, therefore it follows that if the enzyme needed the factor for its activity, phenylglyoxal would not react to give an evolution of $\mathrm{CO}_{2}$.

We hope that further work, which is in progress, may elucidate the role of the new factor.

\section{SUMMARY}

1. A preliminary purification of glyoxalase is described.

2. A new factor, present in tissues, is shown to accelerate the conversion of methylglyoxal to lactic acid.

3. Phenylglyoxal inhibits the factor.

4. The factor has been separated and purified.

\section{REFERENCES}

Hopkins, F. G. \& Morgan, E. J. (1945). 'Biochem. J. 39, Jowett, M. \& Quastel, J. H. (1933). Biochem. J. $27,486$. 320.
Lohmann, K. (1932). Biochem. Z. 254, 332. 